\title{
ARTISTAS, TRABAJADORES Y EMPRENDEDORES: DISYUNTIVAS Y DESAFÍOS DE LA PROFESIONALIZACIÓN DEL CINE CHILENO
}

\author{
Artists, Workers and Entrepreneurs: Crossroads and Challenges \\ of the Professionalization of Chilean Cinema
}

\section{MARÍA PAZ PEIRANO*}

Fecha de recepción: 20 de diciembre de 2019 - Fecha de aprobación: 28 de mayo de 2020

Resumen

Este artículo analiza el proceso de profesionalización del cine chileno reciente. A partir de una etnografía multisituada de larga duración, se da cuenta de los procesos de subjetivación artística y profesional de los y las cineastas chilenos durante la última década y se reflexiona sobre las fisuras de dicho proceso en la experiencia de la "comunidad" de realizadores, agentes clave del campo cinematográfico. El artículo plantea que las prácticas de profesionalización en escuelas y festivales de cine han impactado en los modos de hacer y pensar el cine chileno, tensionando sus marcos de sentido tradicionales y arrastrando una relación conflictiva entre el deber ser y las expectativas del mundo artístico, por un lado, y aquellas del emprendimiento económico del mundo industrial, por el otro. De esta manera, se busca explorar las disyuntivas de la experiencia creativa de estos artistas-profesionales en el marco de las orientaciones neoliberales del Chile contemporáneo.

Palabras clave: profesionalización; campo cultural; mundos de arte; cine chileno; neoliberalismo.

\section{Abstract}

This article analyses the process of professionalization of recent Chilean cinema. Based on a long-term multi-sited ethnography, it gives an account of the way artistic and professional subjectivities of Chilean filmmakers have been constructed in the last decade. This article reflects on the fissures of this process experienced by the "community" of filmmakers, who are key agents of the field of film production. It suggests that professionalization practices in film schools and film festivals have impacted the ways of doing and thinking Chilean cinema, conflicting ideal frameworks of the past, and showing a conflictive relationship between the expectations of the art world, on one hand, and those of the industry and economic enterprise on the other. It seeks to explore the dilemmas of the professional artists' creative experience under the neoliberal orientations of contemporary Chile.

Keywords: professionalization; field of cultural production; artworlds; chilean cinema; neoliberalism.

* Dra. en Antropología Social, Académica del Instituto de la Comunicación e Imagen, Universidad de Chile, Santiago, Chile. Artículo enmarcado en el proyecto Fondecyt № 11160735. Correo-e: mppeirano@uchile.cl 


\section{Introducción}

"Es que como el cine es el más neoliberal de las artes..."

En el contexto de las movilizaciones sociales de octubre de 2019 en Chile, los cabildos autoconvocados (reuniones sociales espontáneas para discutir temas políticos) proliferaron en todo el país, incluidos aquellos eventos que se organizaron por "sector", profesional y/o cultural. La frase citada en el epígrafe corresponde a uno de mis estudiantes de cine que, en la asamblea de la Escuela de Cine de la Universidad de Chile, introducía un tema surgido en el cabildo audiovisual, asumiendo (como varios de los que asintieron a su comentario en la habitación) que el cine era, justamente, "el más neoliberal" de los sectores artístico-culturales chilenos.

No era la primera vez que oía esta frase, la había escuchado de otros participantes en encuentros similares. Tampoco es que me sorprendiera mucho: yo misma había estado estudiando la relación entre cine chileno y neoliberalismo por ya casi una década. Sin embargo, me llamaba la atención esta explícita autoconciencia, puesta a viva voz, cuando antes solo la había identificado como un tímido subtexto bajo las prácticas audiovisuales instaladas en Chile en dicho período. Resultaba también curiosa esa determinación (algo culposa, quizás) de decirse a sí misma "la más" neoliberal de las artes. Sin ánimo de juzgar una declaración que es, cuando menos, difícil de probar, quisiera referirme a este comentario como una viñeta etnográfica inicial que permite enmarcar la discusión que planteo en este artículo.
Este trabajo parte de una investigación etnográfica de larga duración sobre el campo de producción cinematográfico chileno, realizada tanto en Chile como en Europa, en distintos momentos entre 2011 y 2019. Se trató de una etnografía "multisituada" (Marcus, 1995) realizada en dos partes. La primera, entre 2011 y 2014, se realizó en Chile y en festivales internacionales europeos (Cannes, Berlín, IDFA, Londres, DokLeipzig y San Sebastián, entre otros). La segunda parte consistió en un seguimiento intermitente posterior llevado a cabo en distintas ciudades de Chile, entre 2015 y 2019.

La etnografía se basó en la observación participante en espacios de encuentro e intercambio económico, social y cultural entre diferentes agentes del medio nacional (directores, productores, distribuidores, programadores, críticos de cine y técnicos cinematográficos, principalmente), involucrados en la renovación del "campo de producción cultural" (Bourdieu, 1993) del cine chileno. Dicha observación se desarrolló sobre todo en festivales de cine y espacios de encuentro de la "industria" nacional, tales como talleres, laboratorios, mercados, conferencias, charlas públicas y premieres de películas chilenas. A ello se sumó la observación participante en espacios de esparcimiento, tales como fiestas y encuentros informales en bares, cafés y casas de los distintos participantes. Junto con ello, se realizaron entrevistas en profundidad con distintos agentes del campo, enfocadas sobre todo en su trayectoria biográfica, sus prácticas y condiciones de trabajo y sus percepciones sobre el estado del "cine nacional". 
Durante este período, la posición de la observadora fue resituándose desde una observadora externa al comienzo ("la antropóloga" haciendo su tesis sobre cine, cuyo acceso inicial fue posible gracias a algunos amigos en el campo) a una posición de pertenencia relativamente marginal a la comunidad (como académica de la Escuela de Cine y Televisión en la Universidad de Chile). Este enfoque etnográfico multisituado y de larga duración permitió tener una perspectiva longitudinal de las múltiples transformaciones acontecidas en las prácticas de producción, exhibición y circulación del cine chileno en este período, en particular del intenso proceso de "profesionalización" en que se enfoca el presente texto.

En el período de estudio, el campo de la producción cinematográfica se ha transformado, aumentando con creces su producción y su reconocimiento internacional. El cine chileno ha acumulado una cantidad inédita de premios, incluyendo algunos de los más prestigiosos galardones del mundo, como aquellos obtenidos en el Festival Internacional de Cine de Cannes (La cordillera de los sueños, Guzmán, 2019), el Festival Internacional de Cine de Berlín (El club, Larraín, 2015; Una mujer fantástica, Lelio, 2017) y con las primeras nominaciones y premios Oscar en la historia del cine chileno para No de Larraín (2012, nominado en 2013); Historia de un oso de Osorio (2014, ganó en 2016); y Una mujer fantástica (ganó en 2018). El cine nacional ha encontrado un espacio relativamente estable en la programación de festivales internacionales de cine, nodos que funcionan con porteros que legitiman y otorgan valor cultural al cine "de arte" internacional o "cine arte global" (Galt \& Schoonover, 2010). Esto ha permitido al cine chileno $-\mathrm{y}$ de paso, a sus cineastas, productores y técnicos- irse posicionando como una cinematografía reconocida en el campo internacional, del que ha comenzado a formar parte regularmente desde mediados de la década de 2000 (anteriormente su participación había sido más bien puntual, en eventos específicos o con limitada presencia de cineastas y películas nacionales en el circuito).

Este aparente "estallido" del cine chileno en este período puede explicarse como el resultado de la reconfiguración del campo cinematográfico local y su articulación con procesos globales de la industria del cine "de arte" o con cierta adscripción de valor cultural. Su expansión ha implicado el aumento de la producción nacional, asociada a procesos de internacionalización del cine local, la proliferación de redes profesionales en el campo chileno, la diversificación de espacios de exhibición y circulación, y el incremento de iniciativas para la educación formal e informal de los cineastas locales. Esta reconfiguración se relaciona directamente con la industrialización del cine nacional bajo los regímenes del capitalismo tardío, en línea con el desarrollo de las industrias creativas en Chile en el siglo XXI. Tanto desde la iniciativa estatal como de las emergentes agrupaciones de profesionales del cine, se han ido potenciando ciertos ideales y prácticas coherentes con las lógicas de expansión de este tipo de industrias, esto es, la organización de alianzas público-privadas, la generación de redes de trabajo transnacionales, la participación sistemática en el circuito internacional y la profesionalización de directores y productores de cine nacional. Todos estos procesos, en su conjunto, han cambiado no solo las formas de hacer cine chileno, sino también las de comprenderlo y de darle sentido en su doble dimensión de "arte" e "industria". 
Para los agentes del campo chileno, y en particular los y las realizadoras cinematográficos, estas transformaciones han implicado una resignificación de sus prácticas respecto de las tradiciones del cine local, un proceso que no ha estado exento de tensiones y contradicciones. En particular, el proceso de profesionalización del cine chileno ha implicado un replanteamiento de las posibilidades de los cineastas y de su rol como productores culturales, con la experiencia de un cotidiano ambiguo entre ser a la vez parte de un campo artístico y de una emergente industria creativa -dos concepciones que sustentan su trabajo y que se viven, en mayor o menor grado, como un conflicto permanente-. En este artículo, doy cuenta de los procesos de subjetivación artística y profesional de los y las cineastas chilenos y las maneras en que viven dichas contradicciones en su vida cotidiana. El artículo plantea que los cineastas han ido cambiando sus modos de hacer y pensar el cine chileno en un contexto de producción que ha ido transformando sus marcos de sentido de manera intensiva en la última década, arrastrando consigo tensiones fundamentales entre el deber ser y las expectativas del mundo artístico, por un lado, y aquellas del emprendimiento económico del mundo industrial, por el otro. De esta manera, se busca explorar la experiencia de estos artistas-profesionales en el marco de las orientaciones neoliberales del Chile contemporáneo desde una perspectiva etnográfica.

\section{La "industrialización" del cine chileno reciente}

“¿Industria? ¿Cuál industria?”. Inevitablemente, durante el trabajo de campo, alguien ponía esta frase sobre la mesa, ironizando sobre las pretensiones del cine nacional de constituirse en una industria sustentable. No solo los niveles de producción, la inestabilidad económica, la precariedad del trabajo y las pequeñas dimensiones de la producción nacional cuestionan su pertinencia para ser clasificada de "industria", sino también su vocación artística, prefigurada históricamente. Una cinematografía como la chilena, marcada por una mirada artístico-cultural sobre la producción, inevitablemente entraría en tensión con los intentos de cimentar una industria nacional, cuyas lógicas parecen alejarse profundamente del sentido predominante de la práctica cinematográfica local. La lógica de la práctica chilena recoge, así, una aparente contradicción entre "arte" y "negocios" que subyace en la "estructura dualista" (Bourdieu, 1996, p. 100) del cine, una tensión persistente desde la aparición de la noción de "cine arte" en los años veinte. Esta idea ponía en cuestión la vocación comercial que tuvo el cine desde sus orígenes, reclamando su estatus "artístico" por sobre la orientación popular masiva que impulsó su desarrollo industrial. Desde entonces, el cine ha sido defendido por los cineastas independientes como un campo autónomo, bajo la impresión de que la comercialización es, en mayor o menor medida, una amenaza.

Los intentos por industrializar el cine chileno, sin embargo, han estado históricamente en la base del cine nacional como una discusión que ha corrido muy tempranamente en paralelo a la producción, en particular durante el período de entreguerras y la década de 1940. Desde sus comienzos, se vio en el cine chileno la posibilidad de generar un producto que encarnara el desarrollo industrial, un sinónimo de progreso económico que podía, además, devenir en producto de exportación. Esta mirada sobre el cine, que introyectaba los modelos industriales 
con que el cine se había posicionado mundialmente (en particular Hollywood), suponía su carácter comercial y destacaba su rol económico, por sobre otras consideraciones. A pesar de la persistencia de esta concepción, durante los años sesenta esta noción entró en tensión con lo que luego constituiría un epítome del cine de la región, esto es, "el Nuevo Cine" latinoamericano y su vertiente nacional.

El llamado "Nuevo Cine" chileno implicaba un proyecto culturalista de un cine con aspiraciones artísticas, sociales y políticas más allá de las comerciales, que se distanciaba del modelo industrial al que habían aspirado los realizadores locales hasta entonces. En términos generales, las discusiones y obras de los cineastas que podrían adscribirse en esta línea se referían al cine nacional como expresión de la identidad nacional, cuya función social radicaba en enunciar o denunciar la realidad del país. Esto se oponía a los imaginarios impostados del cine espectáculo propiciado por la aspiración industrial, en particular el de Hollywood. El Nuevo Cine, inspirado por los movimientos modernos del cine europeo de los años cincuenta y sesenta, en especial el Neorrealismo italiano y la Nueva Ola francesa (Paranaguá, 2003), se volcó hacia la afirmación de un "cine como arte" que además estuviera involucrado en los procesos de emancipación política que se estaban viviendo en Latinoamérica. Los jóvenes realizadores chilenos se hallaban ya familiarizados con las tendencias del cine europeo de los años cincuenta y sesenta -por ejemplo, como sugieren Salinas, Stange \& Salinas (2008), gracias a su participación en los cine clubes del período- así como con las diversas discusiones sobre el cine moderno, cuyas búsquedas apuntaban a reivindicar la autonomía del cine respecto de los constreñimientos económicos de la industria.

Hacerse parte de estos modos de ver el cine significaba, por una parte, poner en entredicho los modos de producción del cine industrial. El Nuevo Cine aspiraba a producir películas más pequeñas y baratas, filmadas fuera de grandes estudios y con equipos reducidos. Ello suponía una modalidad de trabajo cercana a lo artesanal, fundamentada en relaciones de trabajo cooperativas y tendientes a la horizontalidad. Por otra parte, esto significaba la revalorización de las películas como obras de arte que encarnaban búsquedas estéticas y expresivas particulares, donde el director puede comprenderse como un "autor" por derecho propio, cuya mirada personal del mundo se transfiere a la obra cinematográfica ${ }^{1}$. No solo los realizadores, sino también los críticos chilenos, comienzan a pensar la idea de un "cine de autor" cuyas preocupaciones desbordan las aspiraciones económicas de la obra ${ }^{2}$. Ello contribuirá, a la larga, a la construcción simbólica de una brecha entre el "cine de arte" y el "cine comercial" y a la frecuente sospecha sobre este último -algo que, como señalan Cortínez y Engelbert (2014, pp. 31-33), es persistente en el campo cultural chileno y en su historiografía-.

A ello se suma una tercera consideración que es fundamental en el Nuevo Cine chileno y latinoamericano, el rol sociopolítico de la producción cinematográfica. Frente a la hegemonía económica y cultural de Hollywood sobre el mercado latinoamericano, se propuso un cine alternativo, comprometido con la transformación social. Latinoamérica reafirmaba un cine propio y desafiante en términos geopolíticos, que se organizó en torno a manifiestos que proponían la renovación del cine regional 
en oposición a la hegemonía estadounidense (Pick, 2010). La dimensión política del cine chileno fue gravitante para la definición del "deber ser" del cine nacional, y muy influyente en el desarrollo del campo (en particular en el cine de la Unidad Popular, entre 1970 y 1973). Por lo mismo, estuvo sujeta a múltiples discusiones que dan cuenta de las tensiones entre la construcción de una vanguardia artística y una vanguardia política (cuestión que enfatizan tanto García Espinosa como Getino y Solanas en sus manifiestos cinematográficos, por ejemplo) ${ }^{3}$. Las aspiraciones sobre crear un cine revolucionario tensionan, en especial, la idea del cine de autor, en tanto heredera del imaginario del artista burgués que subraya el rol del individuo creador. Así, la libertad estética del artista y su rol político pueden suponer aspiraciones múltiples y contradictorias en el Nuevo Cine (Mestman, 2016) ${ }^{4}$. Con todo, y a pesar de las diversas disputas al interior del campo, podemos observar un reposicionamiento generalizado de sus agentes en este período en oposición a la idea de "cine industria" que hasta entonces operaba como horizonte de sentido.

Es cierto que no todo el cine chileno producido en los años sesenta puede categorizarse como parte de este "nuevo cine" (Cortínez \& Engelbert, 2014) y que este no formó un movimiento totalmente unitario e indiscutido, tanto en términos estéticos como políticos (Pinto 2016; Mouesca \& Orellana, 2010; Cavallo \& Díaz, 2007). Sin embargo, la idea del nuevo cine chileno y la canonización de ciertas obras y directores del período (principalmente Ruiz, Littin, Francia $y$ Soto) fue especialmente influyente en el desarrollo posterior del campo nacional y en las narrativas sobre el cine chileno que fueron instalándose en las décadas siguientes. Durante los sesenta se vivió un quiebre importante en el campo cinematográfico en el país que marcó luego el imaginario de cineastas, críticos e historiadores chilenos. Más allá de su precisión como categoría histórico-estética, la definición de lo cinematográfico que disputaba el "Nuevo Cine" se convirtió en un referente fundamental para el cine local, como una suerte de momento mítico, y para algunos incluso "fundacional", del campo. Podría argumentarse que había formado parte, al menos hasta la década de 2000, de una especie de "doxa" (Bourdieu, 1977, p. 164), encarnando un modelo que apelaba tanto a la responsabilidad social como a la subjetivación artística de los cineastas.

Los debates sobre la autonomía artística del campo y sus posibilidades de industrialización volvieron a salir a la luz en los años noventa, en la medida en el que el cine recuperaba un espacio en la esfera cultural nacional. Luego del golpe militar de 1973 y durante la dictadura (1973-1990), el Estado chileno abandonó cualquier apoyo legal para el cine chileno mediante el Decreto № 825 (1974), que dejó la producción cinematográfica bajo las regulaciones del libre mercado. Ello, junto con la censura y la persecución política, supuso no solo grandes limitaciones para la producción, sino también la fragmentación del campo, puesto que sus realizadores se mantuvieron dispersos trabajando en el exilio y dentro del país. El período de dictadura estuvo marcado por diversas búsquedas estéticas y políticas que persistieron en, profundizaron y reflexionaron sobre las cuestiones planteadas en las décadas anteriores, en particular sobre el rol político del cine nacional, tanto dentro como fuera del país. Sin embargo, no fue hasta la restitución de un régimen democrático que reflotó la idea de potenciar la "industria nacional". 
Durante los años noventa, el campo cinematográfico chileno se reconfiguró. En este período se potenció el reencuentro de una pequeña comunidad de cineastas que habían desarrollado sus carreras de manera paralela en Chile y el exilio (Pick, 1988; Palacios, 2015) y que habían mantenido y/o construido redes de trabajo y amistad sin apoyo del Estado chileno, tanto en contextos internacionales como dentro de Chile (Liñero, 2010; Palacios, 2016). Como señalan Mouesca y Orellana (2010), el Festival de Cine de Viña del Mar de 1990 fue el evento que marcó dicho reencuentro, reinaugurando un sentido de comunidad entre los realizadores chilenos que se iría reactualizando en las versiones siguientes del festival. Este grupo de cineastas estuvo en el centro de la reconfiguración del campo, tanto rearticulando redes de trabajo nacionales e internacionales, como reorganizándose políticamente en función de las transformaciones institucionales del período y creando espacios para la educación cinematográfica.

Durante estos años se instaló con más fuerza la idea de un "cine de autor" en el campo, noción que circuló en las escuelas de cine, festivales y organizaciones de realizadores del período. Por ejemplo, la Asociación de Directores y Guionistas de Chile (ADG) buscó (y busca aún) promover "la idea del cineasta como un autor" (ADG, 2014a, 2014b), reivindicando los derechos de propiedad intelectual sobre las obras cinematográficas y suponiendo la autoría artística del director/guionista sobre dichas obras. Esta idea de autoría, que reafirmaba la idea de "cine como arte", no supuso, sin embargo, la disociación radical de la idea de industria, sino que fue en su búsqueda. En términos generales, el cine chileno de los noventa buscó conectar con el público local (Cavallo, Douzet \& Rodríguez,
1999) y sus aspiraciones comerciales dentro del mercado local sintonizaron con el antiguo sueño de creación de una industria nacional. $Y$ si bien las aspiraciones políticas del Nuevo Cine también se suavizaron, la cuestión del rol social y la autonomía del campo continuaron siendo ampliamente discutidas entre sus agentes. Así, mientras hablar de "industria" seguía siendo incómodo para algunos realizadores, en mayor o menor medida se buscaba algún éxito de público en las salas que permitiera la sustentabilidad de la producción local.

Este período supuso también la reorganización de los realizadores y técnicos de cine en distintas agrupaciones y asociaciones gremiales ${ }^{5}$ que apoyarían la gestión de cineastas y productores en la búsqueda de apoyo del Estado para el cine chileno. Su trabajo permitió la apertura de fondos de ayuda para la producción, así como una serie de cambios institucionales, incluida la promulgación de la Ley № 19.981 ("Ley del Cine") en 2004. La ley implicó la creación de un programa de fomento de la industria audiovisual administrado por el Consejo Nacional del Arte y la Industria Audiovisual (CAIA) y el consecuente aumento de los fondos de financiamiento para la producción, la difusión y la circulación internacional del audiovisual nacional. La mira en la industrialización se fue convirtiendo en el discurso estatal predominante sobre el cine nacional. El Estado comenzó a buscar financiar este proceso, convirtiéndose en el principal patrocinador de "la industria" del cine chileno, principalmente mediante el Consejo Nacional de la Cultura y las Artes (ahora Ministerio de las Culturas, las Artes y el Patrimonio) y la CORFO (Corporación de Fomento a la Producción), lo que estimuló un crecimiento significativo de la cantidad de producción a partir de la década de 2000 (Trejo, 2009) $^{6}$. 
El Estado chileno ha subvencionado la producción cinematográfica privada mediante diversos fondos concursables, cuyos principales beneficiarios han sido los creadores. Este rol subsidiario del Estado se siguió profundizando en la década de 2010, sumando iniciativas estatales de patrocinio a diversos proyectos de agentes no estatales, ya sean directores de cine, productoras audiovisuales o agrupaciones de profesionales. Entre estas iniciativas encontramos el apoyo de ProChile $^{7}$ a la exportación del cine chileno, lo que ha estimulado la participación de los profesionales chilenos (especialmente directores y productores) en el circuito de festivales internacionales de cine, así como la creación de marcas sectoriales (CinemaChile y Chiledoc) que permiten promocionar las películas chilenas en el mercado internacional mediante la creación de espacios de marketing y networking 8 . Otras formas de apoyo estatal son los fondos para la creación de redes de profesionales (que permitió en primera instancia la creación de Chiledoc), aquellos de intermediación para la educación de jóvenes y público, y los de becas para especialización y posgrado en instituciones de educación superior, todas estrategias que apuntan a la "profesionalización" del sector y a la mejora de sus posibilidades de comercialización.

Vemos entonces que el financiamiento estatal ha buscado apoyar tres ejes para la expansión del cine chileno enmarcados en la idea de "industria audiovisual": el aumento de la producción, la internacionalización y la profesionalización. Estas cuestiones aparecen claramente en la formulación de la Política Nacional Audiovisual (2017-2022) y responden a una línea de base para el desarrollo de todas las industrias culturales nacionales (CNCA, 2011). El interés del Estado ha estado enfocado en promover el cine como sector económico e "industria creativa" de clase mundial, suponiendo que los productores culturales son trabajadores involucrados en la creación de productos con un valor estético y comercial (Hesmondhalgh \& Baker, 2013). Las políticas culturales del Estado chileno tienen como principal destinatario a los profesionales, lo que ha enfatizado las posibilidades de comercialización del cine nacional gracias a su inversión en dichos individuos y en sus empresas productoras. Respondiendo a las transformaciones del capitalismo tardío, la industrialización de la producción cinematográfica en este período pone su acento en fomentar la competitividad y el carácter emprendedor de dichos individuos, valores asociados a su "profesionalización". Esto implica aumentar el número, el grado de especialización y las habilidades laborales de los profesionales del sector, entendidos como el "capital humano" básico de la industria nacional. Como veremos a continuación, estos procesos de profesionalización conllevan ciertas continuidades, tensiones y contradicciones, que evidencian la yuxtaposición entre las aspiraciones industriales y la búsqueda histórica de la autonomía artística del campo.

\section{Procesos de profesionalización de la comunidad cinematográfica chilena}

Una de las principales transformaciones que pueden observarse en el campo cinematográfico chileno, especialmente desde 2010, es su expansión desde una pequeña comunidad de amateurs, cineastas y críticos de cine semiprofesionales a una red profesionalizada de realizadores, gestores y críticos, en la que aún se observan ciertos lazos comunitarios. Como 
hemos mencionado, este proceso empezó a gestarse en la década de 1990, con la renovación institucional y la rearticulación de las redes profesionales en el campo nacional.

Los procesos de profesionalización se han basado en la formalización de la educación cinematográfica, articulada con los procesos de industrialización descritos anteriormente. En Chile, esto ha sido posible por la expansión de una "comunidad de práctica" (Wenger, 1998) de carácter cooperativo, cuyo trabajo y procesos de aprendizaje están marcados por sus relaciones sociales. En el centro del campo de producción nacional podemos encontrar un grupo relativamente pequeño de profesionales, que forman un mundo en el que "todos se conocen" y donde se comparte cierta identidad colectiva como comunidad imaginada del "cine chileno". Gran parte de ellos pertenece a la clase media-alta educada de la sociedad chilena y sus relaciones suelen forjarse tanto mediante el trabajo y el estudio como por la amistad, el matrimonio y el parentesco (lo que lleva a varios de ellos a autodescribirse como un grupo "endogámico", tanto literal como metafóricamente). Sus relaciones están reforzadas por su participación colectiva en proyectos conjuntos, escuelas de cine, festivales de cine locales, encuentros sectoriales, estrenos de las películas y otros eventos sociales formales e informales. Comparten intereses y prácticas cotidianas comunes, ya sea la realización de películas (cineastas, técnicos, productores), su intercambio (distribuidores, expositores) y/o el hablar y pensar sobre ellas (críticos de cine, académicos, representantes institucionales) ${ }^{9}$. Todo ello induce a entenderlos como una comunidad, considerando su "densidad, multiplicidad y configuración sistemática" (Calhoun, 1980, p. 118), definida por ciertos límites simbólicos recalcados en ritos colectivos y por su sentido de pertenencia compartida (Cohen, 1985).

A grandes rasgos, las características de esta comunidad coinciden con la concepción de "mundo del arte" sugerida por Howard Becker, esto es, una "red de personas cuya actividad cooperativa, organizada a través de su conocimiento conjunto de los medios convencionales de hacer las cosas, produce el tipo de obras de arte que el mundo del arte destaca" (Becker, 1982, p. x ${ }^{10}$. Efectivamente, los patrones de cooperación entre la "comunidad" del cine chileno incluyen diversas prácticas más o menos rutinarias, basadas en la reciprocidad, que producen patrones de actividad colectiva. Dichas actividades afectan la producción cinematográfica, marcando el tipo de cine que se realiza de manera predominante en Chile. Esta "comunidad cinematográfica" chilena, sostengo aquí, es una base importante para el "campo de producción cultural" chileno (Bourdieu, 1993), donde los cineastas actúan como agentes clave. Su habitus, o conjunto de disposiciones culturales basadas en la estructura de posiciones ocupadas por los agentes, está incorporado en sus prácticas profesionales.

Dichas prácticas, como detallamos más adelante, se basan en lógicas de producción artística que se trasmiten mediante el trabajo (por ejemplo, durante la filmación y la posproducción), en los espacios educativos formales (las escuelas de cine) y en espacios educativos semiformales en festivales de cine chileno. El conocimiento que se reproduce tanto entre pares como de generación en generación, se fundamenta en prácticas de trabajo colaborativo, por una parte, y en la centralidad de la creatividad individual del autor, por la otra, donde por "autor" se entiende, primordialmente, 
al director de la película (quien muchas veces es también su propio guionista). Estos modos de hacer y pensar el cine promueven un tipo de realización relativamente pequeña, que si bien está basada en el trabajo en equipo, busca concretizar la visión individual del(a) director(a). Dentro de esta lógica es fundamental, entonces, el sentido compartido del valor de las películas producidas colectivamente bajo el paraguas del "cine de autor", con una orientación artístico-cultural que tiende a diferenciarse del cine "comercial", por lo que, como veremos, a la vez se alimenta y entra en conflicto con las pretensiones de industrialización del cine nacional.

\section{Trabajadores modelo y trabajo cooperativo}

En la medida en que el cine es una práctica que requiere, por lo general, de un esfuerzo coordinado y colectivo para su realización, el "trabajar juntos" ha jugado históricamente un papel fundamental en el fomento de un sentido de pertenencia del cine chileno a través de diversas formas de colaboración. La producción cinematográfica puede ser una experiencia muy intensa que implica pasar mucho tiempo junto a otros, tanto en los lugares de filmación como de montaje y posproducción, que suelen motivar intercambios creativos más o menos profundos. En palabras de Gustavo ${ }^{11}$, un director de fotografía:

Para mí, el cine chileno está formado por muchas personas que de alguna manera son parientes... como tus primos o algo así. Entonces, me encuentro de nuevo con personas con las que solía trabajar en los años ochenta, y nos reconocemos [...] Estoy interesado en transmitir esta noción a estos muchachos [los estudiantes], los hago ir y hablar con el cinematógrafo mayor, conocer sus películas y saber que mañana serán colegas, trabajarán en equipos y tal vez en una película donde viven juntos durante cuarenta días como no han vivido con nadie [...] así que me interesa que piensen en el cine no solo como la pequeña familia de compañeros de clase de su misma edad, sino también como una gran familia extendida ${ }^{12}$.

La idea de tener relaciones cercanas, como "de familia", ha resultado muy importante para desarrollar la confianza necesaria que exige una película pequeña, que usualmente se realiza con pocos recursos y depende en gran medida de las voluntades y las competencias personales de los involucrados. De manera similar a lo que sucede en otras industrias pequeñas (Mathieu, 2011), en el caso chileno las diferentes formas de solidaridad y el sentido de comunidad se fortalecen al trabajar repetidamente con las mismas personas en diferentes proyectos cinematográficos. Muchas películas del cine chileno reciente comparten equipos similares, incluidos camarógrafos, cineastas, montajistas, sonidistas y directores de arte. Trabajar juntos en diferentes proyectos ayuda a los profesionales a construir su reputación personal (Zafirau, 2008), además de generar confianza mutua entre los profesionales. La confianza crea, además, una expectativa de trabajo: tanto invitar como aceptar participar en los proyectos de los demás es visto como un signo de reciprocidad, que ayuda a conseguir trabajo en un campo laboral bastante precario.

Como sugiere Ganti (2012), el cine es un negocio que se vive con incerteza por quienes trabajan en él, debido a su imprevisibilidad, a las grandes inversiones que implica y a las dificultades para proporcionar puestos seguros a largo plazo. Ello ha supuesto que, para cinematografías pequeñas como la chilena, el Estado tenga un rol fundamental de apoyo al sector. 
Hemos mencionado que el Estado subvenciona proyectos privados mediante fondos a los que los profesionales postulan cada año por concurso y gracias a los cuales se financia gran parte de las películas chilenas. Ello implica que los "profesionales creativos" chilenos normalmente trabajan por proyecto, sin contratos fijos y dependiendo de este financiamiento (Brodsky, Negrón \& Pössel, 2014). Es extremadamente difícil, por tanto, ganarse la vida únicamente realizando películas y los profesionales necesitan fuentes complementarias de ingresos estables, por ejemplo, como profesores en escuelas de cine. Esta situación refleja las condiciones laborales del capitalismo tardío para los "trabajadores creativos" (Boltanski \& Chiapello, 2005, pp. 166-167), que se están convirtiendo cada vez más en titulares de múltiples empleos de bajo presupuesto (Demazière \& Gadea, 2009; Ross, 2009).

Como hemos visto, el trabajo cooperativo y la orientación "comunitaria" de los y las cineastas chilenos ha estado presente al menos desde los años sesenta, haciendo frente a la precariedad histórica de sus condiciones de producción. Esto ha ayudado a la enseñanza y el aprendizaje de estrategias que les permiten arreglárselas en el contexto contemporáneo, fomentando nuevas formas de cooperación. Los y las profesionales colaboran en diferentes proyectos y trabajan en múltiples roles para asegurar un ingreso ${ }^{13}$, por lo que a menudo intercambian posiciones en la producción de diferentes proyectos cinematográficos. Por ejemplo, directores y directoras han sido productores de la película de otra persona, camarógrafos han sido actores o directores, que a su vez pueden ser consultores de guión en proyectos de otros. Trabajar en diferentes roles no solo es un signo de ayuda mutua, sino de excelencia individual, pues ayuda a cada uno a diversificar sus habilidades y aumentar así las posibilidades de obtener nuevos trabajos en el futuro. Esta práctica también contribuye a la construcción de relaciones de trabajo superpuestas, en las que se desarrollan vínculos sociales aún más fuertes y que proporcionan una sensación de seguridad con respecto a las oportunidades de trabajo futuras (Menger, 1999), lo que disminuye la ansiedad del desempleo y la inestabilidad laboral.

Estos nuevos modos de hacer del cine chileno, si bien rescatan modos de trabajo tradicionales del campo, encarnan además los valores del "paradigma de la economía creativa" (Aronczyk \& Powers, 2010, p. 14) en cuanto potencian la colaboración y el multitrabajo. Sus múltiples habilidades han convertido a los profesionales chilenos en los típicos "nuevos trabajadores modelo" (Ross, 2009, p. 10) de la industria creativa. Responden a las expectativas no solo de ser emprendedores (llevando a cabo sus propios proyectos, siendo autónomos e innovadores), sino también "flexibles", esto es, capaces de trabajar en un contexto inestable, por plazos cortos y cooperativamente o "en red". Sus modos de trabajo se adecúan entonces a las características de un "capital humano" apropiado para el desarrollo posfordista de la industria cultural.

Resulta interesante observar cómo estas expectativas se superponen con actitudes más tradicionales sobre el trabajo artístico. En principio, pareciera que la idea de "trabajadores modelo" de las industrias creativas contemporáneas es contradictoria con los principios de autonomía artística que subyacen al campo, pues apuntan a su calidad como trabajadores y/o empresarios dentro de la lógica industrial. Sin embargo, el relato centrado en los talentos 
individuales, que enfatiza las actitudes y los atributos laborales de los profesionales, se adecúa también a las expectativas sobre los realizadores/artistas del campo. La flexibilidad laboral, las habilidades para el multitrabajo y la consecución de proyectos personales evocan también la libertad y el carácter apasionado del artista moderno, narrativa que se ajusta (no sin tensiones) al paradigma de la economía creativa. Esta superposición puede observarse durante todo el proceso de profesionalización, tanto en las escuelas como en los festivales de cine.

\section{La "profesionalización" y el aprendizaje en las escuelas de cine}

Durante la dictadura cívico-militar las escuelas de cine, incluyendo el Centro de Cine Experimental de la Universidad de Chile, la Escuela de Cine de Viña del Mar, el Instituto Fílmico de la Universidad Católica (Escuela de Artes de la Comunicación desde 1970) y el Departamento de Cine de la Universidad Técnica del Estado (hoy la Universidad de Santiago) cerraron y la carrera de cine dejó de impartirse. La generación de realizadores que se formó durante la dictadura estudió carreras afines (como periodismo), pero no especializadas, en distintas universidades e institutos de comunicación del país. Paralelamente, otro grupo de jóvenes se formó o especializó en el extranjero, principalmente en Europa, Cuba y/o Estados Unidos.

La situación cambió a principios de la década de los noventa con la aparición de las dos primeras escuelas de cine en Santiago: la de la universidad ARCIS (1993) y la Escuela de Cine de Chile (1995). Las nuevas escuelas fueron financiadas por cineastas y críticos de cine formados en los años sesenta y setenta, quienes vieron en ellas la oportunidad de comenzar a reconstituir y profesionalizar el campo (Estévez, 2005). Los nuevos centros educativos fueron la antesala para un aumento considerable en el número de instituciones que podían otorgar títulos de cineasta y comunicador(a) audiovisual durante los años dos mil (Parada, 2011). Ello fue parte de la expansión generalizada del sistema privado de educación como resultado de las políticas neoliberales desarrolladas por los gobiernos chilenos durante este período (Brunner \& Peña, 2008).

El surgimiento y el crecimiento de las escuelas de cine ha tenido un impacto considerable en la cantidad de profesionales especializados y técnicos calificados que desean ingresar al campo de la producción cinematográfica. No solo los directores y los productores, sino también los camarógrafos, los profesionales de sonido, los editores y el personal de posproducción han ido elevando el estándar técnico de la producción local. Para varios de mis entrevistados, esto ha significado un mejoramiento de la "calidad" de las películas, consideradas ahora más cercanas a los estándares internacionales. La especialización también ha supuesto la profesionalización de roles que antes de este período eran muy limitados, lo que ha incidido en sus recientes transformaciones, como los productores y, en menor medida, los teóricos y los críticos de cine.

El rol de los y las productoras profesionales ha sido particularmente relevante respecto de la idea de desarrollo industrial, lo cual ha incidido en la expansión del cine chileno en los últimos veinte años. De manera similar a los productores independientes de Estados Unidos estudiados por Sherry Ortner (2013), el rol de productor 
en Chile ha pasado de ser un financista más bien amateur a un agente creativo fundamental dentro del campo. Su profesionalización desde principios de la década de 2000 apunta a que el productor se involucre en los procesos creativos, dando un giro hacia la promoción del "cine de autor" de orientación artística global que se ha gestado en este período. Productores y productoras, tanto de cine de ficción como de cine documental, han incidido en la realización de obras "independientes", trabajando en estrecha relación con los y las directoras de cine. Además, la Asociación de Productores de Cine y Televisión (APCT) ha desempeñado un papel importante en la implementación de las políticas culturales de los gobiernos del período, incluyendo las estrategias de internacionalización del cine chileno a través del trabajo de CinemaChile y de la agencia de promoción y marca sectorial creada por la APCT (Peirano, 2018). Algunos productores más jóvenes, por otra parte, conformaron de manera más reciente la Asociación de Productores Independientes (API), que busca velar por los intereses de los realizadores y los proyectos de menor escala, que suelen considerarse también los más arriesgados artísticamente.

Respecto de la especialización teórica del campo, las escuelas de cine han permitido también la formación de un pequeño grupo de intelectuales que trabajan como teóricos de cine, críticos, gestores y programadores de festivales, muchos de los cuales son, a su vez, profesores de estas escuelas (como la misma autora de este texto). El grupo ha contribuido a la constitución de un nuevo subcampo de crítica de cine que era casi inexistente en las décadas anteriores (Stange \& Salinas, 2009) y que ha difundido algunas de las narrativas predominantes sobre el cine nacional como esfera artística (incluyendo tanto la reafirmación como la disputa sobre las ideas de autoría artística) construyendo la "relevancia de su valor cultural" (Bourdieu, 1996, p. 167) ${ }^{14}$. Esta línea ha supuesto la actualización de ideas preexistentes en las tradiciones del cine chileno como campo autónomo, en sintonía con la hipótesis del cine como arte, o al menos como patrimonio cultural, que desborda su dimensión económica.

Junto con el fenómeno de especialización, las escuelas de cine son también, como hemos visto, espacios fundamentales para la conformación social y la configuración simbólica del campo cinematográfico al articular educación y práctica profesional. Permiten tanto la formación de lazos intergeneracionales como el refuerzo de los intrageneracionales. Los y las profesoras-realizadoras suelen trabajar activamente en el medio, por lo que se encuentran constantemente con sus colegas en ambos espacios de trabajo. Debido a la precariedad del mundo laboral, suelen enseñar además en varias escuelas al mismo tiempo, reforzando aún más dichos vínculos profesionales. A ello se suma el hecho de que los estudiantes empiezan a constituir sus propios lazos laborales mientras estudian. En la mayoría de los casos, la ópera prima de los profesionales se realizó junto con ex compañeros y compañeras de generación, con quienes siguieron trabajando en varias ocasiones más adelante. Las escuelas de cine funcionan, entonces, como espacios de generación de redes, donde se acumula capital social útil para la vida profesional. En palabras de Vicente, director de cine:

Ha sido difícil para mí porque no asistí a una escuela de cine y Chile funciona de esa manera, debes haber estado en la escuela de cine y tener el título [profesional] para validarte con respecto a los demás... lo que hizo que todo fuera más difícil, porque no era amigo 
de $\mathrm{X}$ y Z, de las personas que se conocían desde ese momento [la escuela]... Yo tuve que hacer todo de lado, y me tomó un tiempo, y mucha paciencia, ser reconocido por ellos ${ }^{15}$.

Dada su constitución social, las escuelas pueden entenderse también como nodos ideales para el intercambio cultural, esto es, espacios para el aprendizaje y la reproducción de formas de hacer y pensar el cine, por ejemplo, para el aprendizaje de las formas de trabajo colaborativo ya mencionadas. Si bien esto puede decirse de toda instancia de educación superior (pensemos, por ejemplo, en el rol que tuvieron las universidades para el surgimiento del Nuevo Cine chileno en los sesenta), esto es particularmente relevante si consideramos su expansión durante la década de 2000. La educación superior incentiva un proceso de profesionalización en sentido estricto (esto es, la entrega de un título profesional o técnico), pero también una serie de lógicas de práctica y sentidos simbólicos sobre la producción cinematográfica. Dado que los mismos profesionales del campo son los que enseñan en las escuelas, estos tienden a transmitir y reforzar su habitus de trabajo y sus ideas sobre el "hacer cine" en Chile, sentando las bases para su consecuente reproducción en el ámbito profesional.

Una de las principales innovaciones en el "hacer cine" (sobre todo de ficción) que se ha reproducido tiene que ver con la menor escala del proceso de filmación. Esto afecta tanto al tamaño del equipo como a la naturaleza de las relaciones de trabajo establecidas durante este proceso. Esto ha potenciado las posibilidades de realización de los más jóvenes, en especial desde fines de los años noventa. Lo anterior se vio facilitado por las estrategias de las escuelas de "aprender haciendo" acercando rápidamente a sus estudiantes a la realización ${ }^{16} y$, sobre todo, por un cambio en las condiciones materiales de producción, que pasaron de las costosas tecnologías de $35 \mathrm{~mm}$ y montaje análogo a la realización de películas digitales y sistemas de edición no lineal.

Desde mediados de la década de 2000, el formato digital HDV significó una reducción considerable en los costos y los tiempos de producción (Larraín, 2010), lo que aumentó las posibilidades de realización de los y las jóvenes cineastas. Hasta entonces, era necesario acumular una gran cantidad de capital económico y simbólico antes de comenzar a hacer películas, y los cineastas debían iniciar sus carreras trabajando en roles menores bajo la línea de producción (sin mucho impacto a nivel creativo), en equipos con relaciones laborales de tipo jerárquico. Ahora, sin embargo, las relaciones verticales en los equipos tienden a ser más débiles y existe mayor independencia de los directores más jóvenes. Esto ha implicado tanto un aumento en la cantidad de óperas primas en el campo (algunas realizadas siendo aún estudiantes $)^{17}$ como la reconfiguración de los equipos de trabajo, circunstancias que promueven el trabajo colaborativo y las relaciones horizontales, reforzando las redes profesionales antes mencionadas.

El foco en la pequeña escala de producción incidió también, por supuesto, en el tipo y la cantidad de películas realizadas al año. Lo que algunos autores han llamado "Novísimo" cine chileno, aludiendo al cine de realizadores jóvenes surgido en los años dos mil (Cavallo \& Maza, 2011), se refirió, en términos generales, a la realización de películas más pequeñas y baratas, que se filmaban con una o dos cámaras y en un número limitado de locaciones ${ }^{18}$. Eran 
películas que tenían solo unos pocos personajes principales y se centraban en "pequeñas historias", que son más fáciles de filmar con pocos recursos. Este cine fue promovido por las instituciones educativas, en particular la Escuela de Cine de Chile. Ejemplo de ello es Sábado (Dir. Matías Bize, 2003), una película "de escuela" (es decir, creada como obra de egreso) que para los editores del libro del Novísimo marcaba un cambio en el cine nacional. La película se produjo utilizando los limitados recursos de la Escuela, bajo los principios de un cine hecho a pequeña escala y de corte autoral. Este tipo de cine, aún predominante en la escena local, concuerda con una concepción más cercana a la de artesanía que a la de industria, pues tiende a asemejar el cine a la producción colectiva de objetos hechos a mano y no a la producción de bienes a gran escala característica de las grandes industrias cinematográficas.

Este estilo de realización parecía, a mediados de la década de 2000, responder mejor al antiguo problema de los altos costos de la producción cinematográfica en contextos precarios como el chileno. Hemos visto que la experiencia histórica del cine nacional había empujado a rechazar de plano la idea de desarrollar una industria de películas de orientación masiva, que compitiera con Hollywood en términos de los denominados "valores de producción" (efectos especiales caros, grandes equipos, largos y costosos horarios de rodaje). En general se ha buscado adoptar, en cambio, estrategias similares a las de otros "cines de naciones pequeñas" (Hjort \& Petrie, 2007), esto es, un modelo de cine de autor de pequeña escala, que responde a las lógicas de producción de cine arte y que se adecúa a las limitaciones materiales de dichos países.
Esta concepción "artesanal" del cine chileno trasmitida en las escuelas de cine sintoniza con una concepción amplia del cine entendido como arte, en particular con aquel centrado en autores, pues se concentra en la creación individual como motor de la producción. Si bien hay diferencias entre las instituciones de educación superior, su énfasis tiende a estar en la formación de realizadores cinematográficos. Parte importante de los estudiantes que ingresan a las escuelas quiere convertirse en directores de cine y, aunque la mayoría de ellos nunca dirija en su vida profesional, sino que se conviertan en técnicos, asistentes de producción u otros similares, aprenden desde temprano que habitualmente la producción cinematográfica es fruto del trabajo de un director que lleva a cabo una idea propia, aun cuando esta se desarrolle en estrecha colaboración con el resto del equipo. Esto marca las expectativas sobre la producción cinematográfica y sobre su propia posición en el campo profesional, pues los estudiantes tienden a asumir estos "modos de hacer" ya establecidos.

\section{Fuera del aula: festivales internacionales, laboratorios y work in progress}

Los procesos recientes de profesionalización del cine chileno están también marcados por las dinámicas internacionales de la industria cinematográfica, en particular su creciente participación en festivales de cine (Peirano, 2016, 2018). La explosión de festivales en Chile en los años noventa y dos mil fue facilitando la expansión de la pequeña comunidad de cineastas que hasta ese entonces había estado en el centro de la producción cinematográfica nacional. Esta expansión potenció sus lazos laborales y 
sociales, y facilitó su profesionalización. A nivel internacional, la participación de los cineastas chilenos en el circuito ha supuesto la incorporación de las lógicas de la industria global en sus propias prácticas de trabajo. La introyección de dichas lógicas y el aprendizaje profesional en los festivales se potencia, además, por su relación con las instituciones educativas. Las escuelas de cine tienden a articularse local e internacionalmente con los festivales de cine, tanto indirecta (por medio de sus profesores, que participan activamente en el circuito) como directamente (a través de la participación de sus estudiantes).

Los festivales de cine conforman una red de exhibición, intercambio y circulación de la industria del "cine independiente" o del "cine arte global" (Galt \& Schoonover, 2010). Si bien han tenido históricamente un rol importante en el apoyo, la difusión y la construcción del cine chileno y el resto del denominado cine "del mundo" (world cinema), sus transformaciones desde la década de 2000 los han convertido en espacios fundamentales para la internacionalización y la profesionalización de la industria del cine independiente. Desde los años sesenta los festivales han sido sitios que apoyan a las cinematografías pequeñas y periféricas (lordanova, Martin-Jones \& Vidal, 2010), ayudando no solo a la distribución de prestigio artístico de las películas y autores, sino también incidiendo en su producción.

Esto se ha profundizado desde los años dos mil, al reorientarse hacia lo que Peranson (2009) denomina como festivales de negocios, centrados en actividades de la industria, fondos de financiamiento, estrenos mundiales y la presencia de figuras internacionales importantes (productores, distribuidores, agentes de ventas, programadores, etc.). En las últimas décadas, estos espacios han contribuido a construir y reproducir la industria internacional del cine independiente global al considerar las películas como productos para consumidores culturales "de nicho" más sofisticados y empaquetándolas con los sellos de prestigio que les otorga el mismo festival. El valor "cultural" y "artístico" de las películas y de los directores (entendidos como "autores globales" de prestigio) supone un valor agregado en el mercado del cine arte global, donde la circulación en el festival implica, eventualmente, la conversión del capital simbólico de obras y realizadores en capital económico.

El circuito internacional de festivales ha funcionado como un espacio de aprendizaje para los profesionales chilenos. La experiencia en festivales refuerza ideas y prácticas aprendidas en la escuela y permite el acceso a nuevas formas de aplicarlas en su propio trabajo de producción, marketing y distribución. Esto vale también para los estudiantes de cine, que están cada vez más cercanos a la experiencia del circuito internacional. Desde 2010, cada vez más festivales han abierto espacios para estudiantes de todo el mundo, ya sea en secciones paralelas que exhiben cortometrajes de egresados y películas de escuela, o en escuelas de verano, residencias y otros programas de capacitación (De Valck, 2013). Un número creciente de laboratorios y work in progress (trabajos en proceso) prestan ayuda y se convierten en guía para la creación, al punto que han empezado a ser parte de una ruta casi obligada para el proceso de producción de una película. Se potencia así el aprendizaje sobre cómo adaptar la obra al mercado internacional respondiendo a ciertos estándares estéticos globales. 
La asistencia a festivales tiende a ser alentada por las escuelas de cine, que ayudan a sus estudiantes a enviar sus películas y brindan capacitación sobre la experiencia festivalera. Las escuelas de cine más pequeñas (como el instituto privado ARCOS) ayudan a los estudiantes a enviar películas a pequeños festivales nacionales, mientras que las que tienen más recursos, prestigio y/o aspiraciones (como la Pontificia Universidad Católica o la Universidad de Chile) tienden a fomentar la participación en festivales internacionales. Por ejemplo, desde 2012 se ha enviado, en distintas ocasiones, delegaciones de estudiantes para presentar sus películas o ser jurado joven al Encuentro Internacional de Escuelas de Cine del Festival de San Sebastián, sección paralela, cuyo objetivo es promover el intercambio de ideas y experiencias entre estudiantes de cine de Europa y América Latina.

Estas experiencias internacionales se han replicado en Chile, pues varios festivales locales (alentados por el financiamiento estatal e intentando congregar mayor público) han tratado de girar también hacia el modelo industrial de festival ${ }^{19}$. En la última década, han proliferado los espacios "de industria" y "mercado" en los festivales, reportándose un número creciente de talleres, laboratorios y work in progress (como Cine del Futuro, de FICValdivia, o el WIP Latam, de SANFIC) que inciden simbólica y económicamente en la producción, dando nueva forma a los proyectos presentados. Son actividades diseñadas para quienes están por terminar sus películas y/o trabajan en etapas específicas del desarrollo de sus proyectos cinematográficos (guión, distribución, estrategias de financiamiento, etc.). Las prácticas de selección y premiación de películas inacabadas, además de los consejos de expertos de la industria sobre los proyectos que se presentan, ayudan a expandir la socialización de los estudiantes en las prácticas globales de producción ${ }^{20}$.

La continuación de la educación superior a través de estos programas de capacitación ha tenido un impacto significativo en la forma en que los y las cineastas más jóvenes ven su propio trabajo. Para muchos de ellos participar de estas instancias parece ser ahora el camino "obvio" y casi rutinario para sus carreras -algo instalado por las generaciones inmediatamente superiores, pero bastante distinto de las prácticas tradicionales de producción, incluso hasta el año 2010-. En el lapso de una década la "laboratorización" de la creación artística se ha generalizado, haciendo aún más evidente el giro del cine nacional hacia la lógica industrial y las tensiones entre este formato y las aspiraciones de autonomía artística de los creadores si se toma en consideración las múltiples negociaciones a las que se somete la obra durante el proceso de creación.

La participación en festivales de cine, como vemos, complementa la educación formal y fortalece los procesos de profesionalización en un campo que se vuelve cada vez más competitivo. Los festivales facilitan la incorporación de los jóvenes al medio a la vez que enfatizan dicha competencia: la sostienen, la gratifican y ayudan a ciertos individuos a escalar posiciones en el campo. Funcionan como porteros que legitiman y distribuyen prestigio entre sus participantes, reposicionándolos como artistas reconocidos del escenario global. Además, facilitan su automejora permanente, alimentando una formación continua que sigue las lógicas de una industria basada en el reconocimiento y la valoración del éxito y la creatividad individual. Para el cine chileno, han supuesto el 
"mejoramiento" colectivo de una fuerza profesional de clase mundial, que incluso tiende a promocionarse como tal en los mercados internacionales de cine (como el Marché du Film de Cannes o el European Film Market de Berlín). Parte del marketing del cine chileno, de hecho, se basa en exportar "los talentos" del cine local, promocionando su carácter de individuos confiables, flexibles y multitasking (los trabajadores ideales). En particular, se enfatiza la imagen de directores y productores como artistas de vanguardia y empresarios o empresarias innovadores, esto es, un capital humano que valoriza aún más el cine nacional dentro del mercado del cine arte global.

\section{¿Artistas, emprendedores o trabajadores?}

El 3 de noviembre de 2011, durante el trabajo de campo, asistí al Primer Encuentro de Escuelas de Cine Chilenas, que tuvo lugar en Santiago. La reunión se llevó a cabo en una pequeña sala de proyección abarrotada en la Cinemateca Nacional y consistió en varias mesas redondas de académicos, académicas y estudiantes de universidades chilenas públicas y privadas. La discusión se centró en el propósito de enseñar cine en Chile, donde se debatieron las formas en que las instituciones chilenas enseñaban cine, los valores que querían transmitir y el futuro de los estudiantes después de la graduación. El debate central, bastante apasionado, fue sobre el propósito de profesionalizar el campo: ¿valía la pena que más y más personas se graduaran en cine? y ¿qué papel jugaban los cineastas en la sociedad chilena?

En principio, el consenso general parecía ser que los profesionales del cine deberían ser conscientes de sus responsabilidades sociales como "constructores de imágenes" opuestas a las de los medios -un acuerdo que evocaba los sentidos tradicionales del campo desde el Nuevo Cine de los sesenta-. Sin embargo, algunos participantes impugnaron tal discurso. Ciertos estudiantes afirmaron que el papel social del cine limitaba su libertad artística y, por lo tanto, debería ser una elección personal. Sostuvieron que el cine debería entenderse "como una profesión más" y, por lo tanto, como una actividad que ameritaba recompensa económica. Estaban preocupados por las precarias condiciones de trabajo en Chile y declararon que el cine debía ser sostenible, que el público chileno debía consumirlo y que los estudiantes de cine debían aprender también de negocios.

Para algunos estudiantes más politizados, este fue un momento decisivo en el debate. Ellos también querían que la gente viera sus películas, pero se preguntaban cuánto tendrían que "vender" para ello, tanto sus convicciones sociales como la "libertad artística" que los demás decían defender. Un estudiante del panel señaló: "¡Yo no quiero hacer películas como... como las de Nicolás López! [risas masivas de la audiencia], películas sin contenido, solo hechas para complacer al público". Otro estudiante respondió desde atrás: "Yo tampoco, poh wn. Quiero decir, jobvio que tampoco quiero ser como Nicolás López! [más risas de la audiencia]. Pero todavía quiero ganarme la vida... ¡y quiero tener un público!"21.

La discusión continuó en esta línea y durante un buen rato se siguió utilizando el ejemplo del director Nicolás López, usándolo una y otra vez como un ejemplo de todo lo que estaba mal en el cine. López fue por mucho tiempo uno de los pocos cineastas en tener éxito comercial en las carteleras chilenas. Relativamente joven y abier- 
tamente desinteresado en la dimensión artística del cine, encarnaba una aspiración mercantil a la que todos los demás parecían oponerse. Su nombre se usó aquí como una estrategia de diferenciación, lo que permitió a los estudiantes posicionarse en el lado "correcto" de los ideales del campo, al tiempo que los ayudaba a construir sus propias subjetividades como cineastas, incluso si decidieron defender, hasta cierto punto, la idea del cine como industria.

Esta reseña etnográfica pone en evidencia las tensiones que han estado imbricadas en el proceso de profesionalización descrito en las páginas anteriores. Los profesionales chilenos tienden a posicionarse en algún lugar en un espectro entre nociones aparentemente opuestas sobre el cine: por una parte, como una forma de arte y un modo de expresión individual que el Estado debe preservar, proteger y promover, entendiéndolo como un bien colectivo "cultural" y un campo autónomo. Por otra parte, para otros, que entran más en sintonía con las políticas estatales, el cine se entiende como una "industria" que debe ser sostenible económicamente, patrocinada por el Estado como un negocio emergente. Dadas las condiciones de trabajo y las dinámicas de la industria contemporánea que hemos expuesto, ambas nociones ideales se yuxtaponen en la práctica y la gran mayoría de los profesionales no pueden sostener una pura y única posición.

El cine chileno sigue siendo, en este sentido, un campo cultural en disputa. Las nociones superpuestas sobre el cine que se han desarrollado en Chile condicionan la experiencia cotidiana de los miembros de la comunidad, ya que generan expectativas sociales contradictorias respecto de su quehacer, su posición y su identidad de "profesional". En las comunidades de cine arte como a la que ha aspirado históricamente la chilena existe una preocupación constante por la legitimación artística (Ramey, 2002), pues el reconocimiento está vinculado a una obra y reputación personales que se adecúan a los discursos normativos de lo que el cine chileno "debería ser". Por otra parte, al considerar al cine como una actividad económica y a sí mismos como profesionales, los cineastas también buscan otro tipo de reconocimiento, uno que apela a la legitimidad del trabajo cultural y a las posibilidades de supervivencia. Las diferentes concepciones establecen un "espacio de posibilidades" (Bourdieu, 1993, p. 65) o categorías de percepción que pueden ser contradictorias y que alimentan ansiedades, reflexiones y juicios normativos sobre el cine chileno: aquello que se valora como una estética "correcta", como un éxito de público aceptable, qué películas los realizadores creen que pueden hacer, distribuir y exhibir, y quiénes se supone que son sus públicos. En este escenario, las múltiples expectativas sobre los agentes del campo parecen a veces irresolubles.

Desde el Encuentro de Escuelas del relato etnográfico ha pasado casi una década, tiempo en que se ha instalado aún con más fuerza la idea de industria entre los realizadores más jóvenes. Si bien las narrativas tradicionales sobre el cine como un arte crítico y comprometido, definido ética y políticamente, se siguen valorando (sobre todo por los críticos de cine), la principal superviviente de esas narrativas es la idea de autoría artística moderna. Se suelen legitimar y poner en valor las obras de realizadores que encarnen un cine nuevo, de vanguardia, que discuten las tradiciones hegemónicas y que se oponen al cine "comercial". El cine como arte, creado por artistas con un estilo reconocible, sigue siendo un "régimen 
de valor revelador" (Myers, 2001, p. 8) del cine local, aun cuando marginalmente se escuchen voces disidentes que cuestionen la centralidad de esa autoría. Esa idea de autor, sin embargo, está permeada cada vez más por una noción de "innovación", creatividad y productividad que es propia de la lógica industrial. La autoría, en este contexto, ha sido un pilar importante para la activación de una industria que valora por sobre todo las capacidades creativas y de trabajo cooperativo de los individuos involucrados en la producción cinematográfica. Tales individuos tienden, además, a una apasionada autoexplotación de sus recursos cognitivos, enmarcada en el relato de la libertad artística.

Vemos que la vieja tensión entre arte e industria del cine se ha rearticulado, en el caso chileno, con la expansión neoliberal de la industria local en el capitalismo posfordista o "capitalismo cognitivo" (Ossa, 2016), en el que predomina la doctrina del Self, en su dimensión de creatividad, conocimiento y trabajo personal, bajo el supuesto de la libertad individual y la multiplicidad, lo cual marca tanto la producción como los procesos de subjetivación de los realizadores. Como señala Lazzarato (2004), en este contexto la producción intelectual tiende a verse subordinada a la producción económica, en la que "el trabajo artístico tiende a convertirse en uno de los modelos de la producción de la riqueza" (p. 139), cuestionando su diferenciación respecto de otros modos de trabajo, así como la misma oposición entre arte e industria.

La experiencia de profesionalización del cine chileno resalta estas transformaciones y pone en el tapete los desafíos de hacer cine considerando el acento en el emprendimiento y la empresa individual que se le da a la producción cultural bajo el neoliberalismo. Las tensiones a las que se enfrentan los sujetos enfatizan, específicamente, las paradojas de la producción de cine arte y, en particular, el cine "de autor" en el capitalismo tardío. Como sugieren Boltanski y Chiapello (2005), las aspiraciones artísticas y emancipadoras de la crítica cultural, que aún son fundamentales para la construcción de las subjetividades artísticas contemporáneas, han tendido a ser capturadas y mercantilizadas en la economía posindustrial. En estas condiciones, construir identidades artísticas autónomas muestra las dificultades de conciliar la acumulación de capital simbólico, cultural y económico con las expectativas y las delimitaciones simbólicas del campo. En el caso chileno, los regímenes de valor se superponen, evidenciando las contradicciones más amplias de la experiencia del neoliberalismo.

\section{Conclusiones}

El proceso de profesionalización del cine chileno ha sido fundamental para la expansión del campo de producción cinematográfica en la última década. Hemos visto cómo el grupo de conocidos, amigos y compañeros de trabajo que conformaba la comunidad cinematográfica chilena hasta los noventa fue expandiéndose en una pequeña red profesional que continúa cimentando relaciones cercanas y permitiendo la transmisión de diversos "modos de hacer" y "modos de pensar" el cine local. Si hasta los noventa los cineastas hacían carrera dentro de equipos de producción, basándose en una práctica más amateur, desde los años dos mil la enseñanza de los jóvenes cineastas está marcado cada vez más por la educación formal. Su aprendizaje depende no solo de su práctica laboral, sino también de su paso por 
escuelas y festivales de cine, que funcionan como espacios educativos complementarios. El proceso de aprendizaje profesional implica el establecimiento y la reproducción de redes sociales, así como la incorporación de tendencias, valores y normas estéticas en su propia práctica. Todo ello ha servido a la expansión y el posicionamiento del cine chileno reciente como un cine de arte global, si bien esto conlleva una serie de tensiones respecto a su propia configuración como campo artístico.

Los procesos de profesionalización del cine chileno implican una concepción del cine como industria creativa que, articulándose con los imaginarios del cine de autor que subyacen al cine arte global contemporáneo, conflictúan la noción del cine como una esfera autónoma y las expectativas tradicionales de la comunidad local. El discurso del cine como valor artístico-cultural continúa siendo una narrativa predominante del campo, aunque algunos agentes la cuestionen, considerando sus aspiraciones industriales. La idea de excepción cultural, que presupone una diferencia cualitativa entre trabajo industrial y trabajo artístico, resulta comprometida por las lógicas del capitalismo cognitivo, donde la creatividad individual y la autoría no solo funcionan como parte de la expresión personal, sino también como base para la productividad económica del sector. Esto implica procesos de subjetivación donde la distinción arte/no arte se vuelve borrosa. La comunidad de profesionales pone en práctica y difunde los valores necesarios de los "trabajadores modelo" del paradigma de la economía creativa a través de la educación formal y la capacitación informal, encarnando y promoviendo actitudes que los hacen, al mismo tiempo, artistas innovadores, emprendedores autónomos y trabajadores flexi- bles y multitasking. Su capacidad de establecer y mantener redes profesionales (donde se superponen amistad y trabajo) tiene su origen en su propia conformación "comunitaria", potenciada y recreada bajo las lógicas del capitalismo posfordista.

La experiencia del campo cinematográfico chileno da cuenta de algunas de las paradojas de la producción cultural bajo un modelo neoliberal. Considerando aquí el neoliberalismo tanto un sistema económico como una construcción ideológica anclada en los principios de la economía de libre mercado (basado en valores como la libertad económica, la privatización y la empresa individual), asumimos que no solo provee contextos estructurales para el intercambio económico, sino también imaginarios culturales específicos, reelaborados a nivel local. En el caso chileno, estos imaginarios están vinculados al sistema impuesto por la fuerza durante la dictadura, que dio forma a las condiciones sociopolíticas del Chile actual y que, irónicamente, ha permitido el florecimiento del cine chileno contemporáneo mediante las políticas neoliberales de un Estado subsidiario, que enfatiza el cine como sector económico y la profesionalización de los cineastas como motor para su expansión. Es en este sentido que realizadores, productores, críticos y estudiantes pueden vivir el cine como "el más neoliberal de las artes", como mencionábamos al principio de este artículo: tanto como un arte crítico e innovador, por una parte, como un negocio y emprendimiento creativo, por la otra. En tanto se siga sosteniendo un ideal de resistencia cultural y autonomía artística que desafíe su propio quehacer, su constitución seguirá siendo problemática, como el de todo campo en disputa. 


\section{Notas}

${ }^{1}$ Astruc describió algunas de estas ideas en su influyente ensayo sobre la "cámara como pluma". Estas fueron ampliadas luego por el cineasta y crítico francés François Truffaut y la revista Cahiers du Cinéma, asociada a la Nueva Ola francesa. Astruc argumentó que el cine era una forma en la cual un artista puede expresar sus pensamientos, por abstractos que sean, o bien traducir sus obsesiones, exactamente como lo hace en el ensayo o la novela contemporánea: "Es por eso que me gustaría llamar a esta nueva era del cine la era del camera-stylo (cámara-pluma)" (2009 [1948], p. 32). La alianza entre crítica y cine promovió durante los años cincuenta una "política de autores" en esta línea, la cual posiciona al director como principal agente creativo de una obra con estilo propio y reconocible, valorable como tal. Esto entraría más adelante en tensión con la politización del cine de las "nuevas olas" (sobre todo después de 1968), en la medida que la autoría podía asociarse con una visión burguesa del arte centrada en los individuos creadores, en contradicción con las miradas marxistas sobre la producción cultural que se discutían en dicho período. Esta discusión se encuentra también en el Nuevo Cine latinoamericano, como se menciona en este artículo.

${ }^{2}$ Esto no significa que en las décadas anteriores se ignorara el trabajo de directores de cine en Chile, sin embargo, su análisis crítico en términos de autoría artística empieza a formarse durante este período.

3 "Por un cine imperfecto" (Julio García Espinosa, 1969) disponible en https://www.programaibermedia.com/julio-garcia-espinosa-porun-cine-imperfecto/y "Hacia un tercer cine: Apuntes y experiencias para el desarrollo de un cine de liberación en el tercer mundo" (Octavio Getino y Fernando "Pino" Solanas, 1969) disponible en https://cinedocumentalyetnologia.files.wordpress.com/2013/09/ hacia-un-tercer-cine.pdf

${ }^{4}$ Sobre estas discusiones en el Nuevo Cine chileno, ver Pinto (2016).

${ }^{5}$ En este período se crearon organizaciones que se sumaron a la APCT (Asociación de Productores de Cine y Televisión, fundada en 1979), como la ACORCH (Asociación de Cortometrajistas de Chile, 1993), SINTECI (Sindicato Nacional Interempresa de Profesionales y Técnicos del Cine y Audiovisual, 1994), ADOC (Asociación de Documentalistas, 1998) y ADG (Asociación de Directores y Guionistas Cinematográficos de Chile, 2004). El antecedente de la ADG fue la APTA, organización de cineastas que lucharon contra la censura y la persecución política durante la dictadura y que ayudaron a crear las primeras instituciones culturales y cinematográficas durante los años noventa (ADG, 2014a, 2014b).

${ }^{6}$ Antes de la década de 1990, se estrenaban menos de 10 cintas chilenas al año, mientras que en ella este número se elevó a 25. Luego aumenta consistentemente y en los años 2010 el promedio llega a 132. Fuente: CAEM (2019).

${ }^{7}$ ProChile es una institución que depende del Ministerio de
Relaciones Exteriores, encargada de la promoción de la "oferta exportable de bienes y servicios chilenos" (Recuperado de https:// www.prochile.gob.cl/landing/quienes-somos/).

${ }^{8}$ Para mayores detalles sobre los procesos de internacionalización del cine chileno reciente ver Peirano (2018).

${ }^{9}$ Esta constitución comunitara involucra también, por lo tanto, a la autora de este texto, como académica y como amiga de algunos de los agentes del campo (quienes facilitaron el acceso durante la investigación). Esta posición de observación implica necesariamente una dimensión reflexiva en torno a las relaciones personales establecidas en el campo, ampliamente desarrollada en Peirano (2015).

${ }^{10}$ En inglés en el original, traducción de la autora.

${ }^{11}$ Para resguardar su anonimato, todos los nombres de los participantes en la investigación se encuentran cambiados en este artículo.

${ }^{12}$ Entrevista personal, Gustavo (50 años), 2012.

${ }^{13}$ Esto es especialmente relevante para las mujeres profesionales del campo, que por lo general trabajan de forma cooperativa. Para más detalles ver Bossay y Peirano (2017).

${ }^{14} \mathrm{Si}$ bien existen de manera reciente diversas discusiones y posturas teóricas que discuten la idea del "autor" individual en la creación cinematográfica, el aumento de los estudios sobre directores y directoras de cine chileno ha relevado a creadores y obras, sirviendo de sustento narrativo para esta dimensión discursiva del campo nacional.

${ }^{15}$ Entrevista personal, Vicente (40 años), 2013.

${ }^{16}$ Dichas prácticas se aprenden generalmente en los cursos de taller, donde los y las estudiantes aprenden a filmar "haciendo", a través de un "compromiso atento" con la tecnología, que incide en su proceso creativo (Ingold, 2001, p. 22). Esto es fundamental para la formación, puesto que los talleres prácticos son la columna central del plan de estudios, mientras que las clases de teoría e historia suelen ser módulos secundarios.

${ }^{17}$ Los y las jóvenes han podido incluso empezar a trabajar en sus propios proyectos desde los primeros meses de su carrera, lo que implica que al graduarse ya tienen experiencia de rodaje e incluso que algunas de sus obras "amateur" estén circulando en festivales de cine o en Internet (Youtube o Vimeo).

${ }^{18}$ Utilizo aquí el concepto de "Novísimo Cine chileno" de manera referencial, puesto que el término se encuentra ampliamente difundido en el campo nacional desde la publicación de dicho libro: un texto inédito en el país, pues se refería, por primera vez, de forma más o menos sistemática, a la generación de nuevos "autores" jóvenes del cine nacional. Tanto el concepto como la selección de realizadores que aparecen en esta recopilación no dejan de ser discutibles (sobre todo tras casi una década de su publicación), sin que por ello el concepto pierda validez como categoría emic que distingue un quiebre generacional e involucra nuevos modos de hacer cine 
respecto de las décadas anteriores.

${ }^{19}$ Organizaciones privadas de financiamiento público, como CinemaChile y ChileDoc, también han ofrecido, desde 2010, una serie de talleres y clases magistrales que conectan a estudiantes y profesionales con las prácticas internacionales de distribución y exhibición.

\section{Referencias bibliográficas}

ADG (2014a). Para el Chile que soñamos, el cine que queremos: Un proyecto en construcción: hacia el Instituto Nacional del Audiovisual. Asociación de Directores y Guionistas de Chile. Documento de trabajo. (2014b). Quiénes somos en la Asociación de Directores y Guionistas de Cine de Chile. Asociación de Directores y Guionistas de Chile. Documento de trabajo.

Aronczyk, M. \& Powers, D. (2010). Blowing up the brand: Critical perspectives on promotional culture. Londres: Peter Lang.

Astruc, A. (2009 [1948]). The birth of a new avant-garde: La Caméra-Stylo. En Vincendeau, G. \& Graham, P. (Eds.), The French new wave: Critical landmarks (pp. 31-37). Hampshire: Palgrave Macmillan.

Becker, H. S. (1982). Art worlds. Berkeley: University of California Press.

Boltanski, L. \& Chiapello, E. (2005). The new spirit of capitalism. International Journal of Politics, Culture, and Society, 18(3), 161-188. doi: 10.1007/s10767-006-9006-9.

Bossay, C. \& Peirano, M. P. (2017). Parando la olla documental: Women and contemporary chilean documentary film. En Martin, D. \& Shaw, D. (Eds.), Latin American women filmmakers (pp. 70-98). Londres: I.B Tauris.

Bourdieu, P. (1977). Outline of a theory of practice. Cambridge: Cambridge University Press.

(1993). The field of cultural production: Essays on art and literature. Nueva York: Columbia University Press.

(1996). The rules of art: Genesis and structure of the literary field. Standford: Stanford University Press.

Brodsky, J., Negrón, B. \& Pössel, A. (2014). El escenario del trabajador cultural en Chile, Proyecto Trama. Santiago: Observatorio de Políticas Culturales.

Brunner, J. \& Peña, C. (2008). La reforma al sistema de educación superior: Claves para el debate. Santiago: Universidad Diego Portales.

CAEM (2019). El cine en Chile en el 2018: Informe de la Cámara de Exhibidores de Chile. Recuperado de http://www.caem.cl/index. php/informes-anuales/item/28-el-cine-en-chile-en-el-2018.

Calhoun, C. (1980). Community: Toward a variable conceptualization for comparative research. Social History, 5(1), 105-129. doi: 10.1080/03071028008567472.

Cavallo, A. \& Díaz, C. (2007). Explotados y benditos: Mito y desmitificación del cine chileno de los 60. Santiago: Uqbar.

Cavallo, A. \& Maza, G. (2011). El novísimo cine chileno. Santiago: Uqbar.
${ }^{20}$ Los expertos suelen ser profesionales locales con experiencia internacional o bien representantes de los mismos festivales internacionales (ya sea Locarno, Cannes, Berlín, Mar del Plata o Buenos Aires).

${ }^{21}$ Notas de campo, Santiago de Chile, 3 de noviembre de 2011.

Cavallo, A., Douzet, P. \& Rodríguez, C. (1999). Huérfanos y perdidos: El cine chileno de la transición 1990-1999. Santiago: Grijalbo.

CNCA (2011). Política cultural 2011-2016. Consejo Nacional de la Cultura y las Artes. Recuperado de https://www.cultura.gob.cl/.

Cohen, A. P. (1985). The symbolic construction of community: Key ideas. Chichester: Ellis Horwood.

Cortínez, V. \& Engelbert, M. (2014). Evolución en libertad: El cine chileno de fines de los sesenta. Santiago: Cuarto Propio.

Demazière, D. \& Gadéa, C. (2009). Sociologie des groupes professionnels: Acquis récents et nouveaux défis. París: La Découverte.

De Valck, M. (2013). Sites of initiation: Film training programs at film festivals. En Hjort, M. (Ed.), The education of the filmmaker in Europe, Australia, and Asia. (pp. 127-145). Nueva York: Palgrave Macmillan.

Estévez, A. (2005). Luz, cámara, transición: El rollo del cine chileno de 1993 al 2003. Santiago: Radio Universidad De Chile.

Galt, R. \& Schoonover, K. (2010). Global art cinema new theories and histories. Oxford: Oxford University Press.

Ganti, T. (2012). Producing Bollywood: Inside the contemporary Hindi film industry. Durham: Duke University Press.

Hesmondhalgh, D. \& Baker, S. (2013). Creative labour: Media work in three cultural industries. Londres: Routledge.

Hjort, M. \& Petrie, D. J. (2007). The cinema of small nations. Edimburgo: Edinburgh University Press.

Ingold, T. (2001). Beyond art and technology: The anthropology of skill. En Schiffer, M. B. (Ed.), Anthropological perspectives on technology (pp. 17-31). Dragoon: Amerind Foundation.

Iordanova, D., Martin-Jones, D. \& Vidal, B. (2010). Cinema at the periphery. Detroit: Wayne State University Press.

Larraín, C. (2010). Nuevas tendencias del cine chileno tras la llegada del cine digital. Aesthesis, 47, 156-171. doi: 10.4067/S071871812010000100011.

Lazzarato, M. (2004). Tradición cultural europea y nuevas formas de producción y transmisión del saber. En Blondeau, O. \& Sánchez Cedillo, R. (Eds.), Capitalismo cognitivo: Propiedad intelectual y creación colectiva (pp. 129 - 144). Madrid: Traficantes de Sueños,

Liñero, G. (2010). Apuntes para una historia del video en Chile. Santiago: Ocho Libros.

Marcus, G. (1995) Ethnography in/of the world system: The emergence of multi-sited ethnography. Annual Review of Anthropology, 24, 95-117. doi: 10.1146/annurev.an.24.100195.000523.

Mathieu, C. (2011). The cultural production and career in the Danish 
film industry: The ideological symbiosis of "auteur" and "craftsperson". Creative Encounters Working Paper 68. Frederiksberg: Department of Organization, Copenhagen Business School.

Menger, P. (1999). Artistic labor markets and careers. Annual Review of Sociology, 25, 541-574. doi: 10.1146/annurev.soc.25.1.541.

Mestman, M. (2016) (Coord.). Las rupturas del 68 en el cine de América Latina. Buenos Aires: Akal.

Mouesca, J. \& Orellana, C. (2010). Breve historia del cine chileno: Desde sus orígenes hasta nuestros días. Santiago: LOM.

Myers, F. (2001). The empire of things: Regimes of value and material vulture. Melton: James Currey Publishers.

Ortner, S. (2013). Not Hollywood: Independent film at the twilight of the American dream. Duhram: Duke University Press.

Ossa, C. (2016). El ego explotado: Capitalismo cognitivo y precarización de la creatividad. Santiago: Departamento de Artes Visuales, Universidad de Chile.

Palacios, J. M. (2015). Chilean exile cinema and its homecoming documentaries. En Prime, R. (Ed.), Cinematic homecomings: Exile and return in transnational cinema (pp. 147-68). Nueva York: Bloomsbury. (2016). Resistance vs. exile: The political rhetoric of Chilean exile cinema in the 1970s. Jump Cut, Review of Contemporary Media, 57. Recuperado de https://www.ejumpcut.org/archive/jc57.2016/PalaciosChile/text.html

Parada, M. (2011). El estado de los estudios sobre cine en Chile: Una visión panorámica 1960-2009. Razón y Palabra, 77. Recuperado de http://www.razonypalabra.org.mx/.

Paranaguá, P. A. (2003). Tradición y modernidad en el cine de América Latina. Madrid: Fondo de Cultura Económica.

Peirano, M. P. (2015). Contemporary Chilean cinema: Film practices and narratives of national cinema within the Chilean "film community". (Tesis inédita de doctorado). University of Kent, Canterbury. (2016). Pursuing, resembling and contesting the global: The emergence of Chilean film festivals. New Review of Film and Television
Studies, 14(1), 112-131. doi: 10.1080/17400309.2015.1109345. (2018). Festivales de cine y procesos de internacionalización del cine chileno reciente. Cuadernos.info, 43, 57-69. doi: 10.7764/ cdi.43.1485.

Peranson, M. (2009). First you get the power, then you get the money: Two models of film festivals En Porton, R. (Ed.), Dekalog 3: On film festivals (pp.23-37). Londres: Wallflower.

Pick, Z. (1988). Chilean Cinema in exile (1973-1986): The notion of exile: A field of investigation and its conceptual framework. Framework, 34(1988), 39-57.

(2010). The new Latin American cinema: A continental project. Austin: University of Texas Press.

Pinto, I. (2016). Crítica y crisis en el Nuevo Cine. En Mestman, M. (Coord.), Las rupturas del 68 en el cine de América Latina (pp. 185-216). Buenos Aires: Akal,

Ramey, K. (2002). Between art, industry and academia: The fragile balancing act of the avant-garde film community. Visual Anthropology Review, 18(1), 22-36.

Ross, A. (2009). Nice work if you can get it: Life and labor in precarious times. Nueva York: New York University Press.

Salinas, C., Stange, H. \& Salinas, S. (2008). Historia del cine experimental en la Universidad de Chile, 1957-1973. Santiago: Uqbar.

Stange, H. \& Salinas, C. (2009). Hacia una elucidación del campo de estudios sobre cine en Chile. Aisthesis, 46, 270-283. doi: 10.4067/ S0718-71812009000200015

Trejo, R. (2009). Cine, neoliberalismo y cultura: Crítica a la economía política del cine chileno contemporáneo. Santiago: ARCIS.

Wenger, E. (1998). Communities of practice: Learning, meaning, and identity. Cambridge: Cambridge University Press.

Zafirau, S. (2008). Reputation work in selling film and television: Life in the Hollywood talent industry. Qualitative Sociology, 31(2), 99-127. doi: 10.1007/s11133-007-9083-8. 